\title{
Calcitonin Stimulation Tests: Rationale, Technical Issues and Side Effects: A Review
}

\author{
Authors

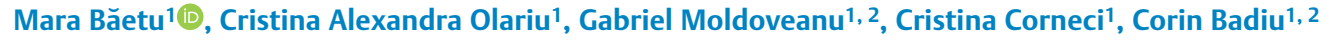

\author{
Affiliations \\ 1 “C.I. Parhon" National Institute of Endocrinology, \\ Bucharest, Romania \\ 2 "Carol Davila“ University of Medicine and Pharmacy, \\ Bucharest, Romania
}

Key words

calcitonin, stimulation test, side effects, safety

received 29.12.2020

accepted after revision $\quad 14.04 .2021$

Bibliography

Horm Metab Res 2021; 53: 355-363

DOI 10.1055/a-1487-6449

ISSN 0018-5043

C 2021. Thieme. All rights reserved.

Georg Thieme Verlag KG, Rüdigerstraße 14,

70469 Stuttgart, Germany

Correspondence

Mara Băetu M.D. Ph.D. Student

"C. Davila" University of Medicine and Pharmacy

"C.I. Parhon" National Institute of Endocrinology

34-38 Aviatorilor Bvd

011863 Bucharest

Romania

Tel: + 40741498229

mara.baetu@drd.umfcd.ro

\section{ABSTRACT}

Calcitonin (CT) stimulation tests have great value and could help to: differentiate thyroid causes of elevated CT apart from non-thyroid sources, determine whether the patients with slightly elevated basal CT could/could not be candidates for surgery, and indicate the right moment for prophylactic thyroidectomy in children with MEN syndromes when with normal basal CT. This triggered the requests for development of CT stimulation tests, taking into consideration their safety and aimed us to write a systematic review of literature regarding the rationale, technical issues, and side effects of CT stimulating tests used for diagnosis of MTC. After a thorough review of the literature, we classified the reported side effects by severity, as defined by United States Food and Drug Administration. A statistical analysis was performed using IBM SPSS Statistics version 20. Various side effects were noticed during stimulation tests that differ by intensity, duration and severity, depending on types of substances and protocols used. The side effects after pentagastrin test were significantly more severe than those reported after calcium stimulation test ( $p=0.0396)$. There are also significant gender-specific differences in side effects induced by stimulation tests. In conclusion, we recommend performing Ca CT stimulation test when needed, considering preventive evaluation of some clinical, instrumental, and biochemical aspects of each patient. Precise instructions should be followed before a stimulation test and furthermore continuous cardiac monitoring is essential during and after the test to minimize the possibility of a serious event.

\section{Introduction}

Medullary thyroid carcinoma (MTC) can be cured only by complete resection of the thyroid tumor and any local and regional metastases [1], thus the prognosis is good when the disease is diagnosed in the early localized stage. Progress of calcitonin (CT) assays and different reference cut-off values changed the cut-off level for MTC diagnosis [2-7]. While very high CT levels are representative for MTC $[8,9]$, a small increase of CT values in addition to thyroid nodules might increase concern for undiagnosed small MTC. Current revised MTC guidelines do not specify reference ranges of basal or stimulated serum CT levels for the diagnosis of MTC, recommending that laboratories set their own reference ranges based on studies of large numbers of normal patients and patients with MTC [9]. This triggered the requests for development of CT stimulation tests. Several substances and protocols have been used over time for stimulation of CT secretion, even though the rationale behind each substance is not explicit. Some of them proved to be efficient in early diagnosis of MTC, like calcium (Ca), pentagastrin $(\mathrm{Pg})$ or the combined $\mathrm{Pg}$-Ca test. Other agents like omeprazole, glucagon, thyrotropin-releasing hormone (TRH), alcohol, histamine, lysine vasopressin, peptones, synthetic C-terminal octapeptide of porcine cholecystokinin-pancreozymin (C8-CCK), or purified, native swine extract of cholecystokinin-pancreozymin (CCK) had only been tested in small series.

The indication to perform CT stimulating tests has changed in the last years. First of all, they may help to differentiate thyroid causes of elevated CT apart from non-thyroid sources [6, 9]. Second, when basal CT is in the grey zone (a mild elevation between normal 
and assay-and-gender specific published thresholds), a stimulation test may help determine whether the patients could be candidates or definitively not be candidates for surgery $[6,7,10]$. Third, in inherited syndromes that involve C-Cell disease, when basal CT is normal, a stimulation test can help indicate the right moment for prophylactic surgery in children [9-11].

Calcium is the current gold standard of CT stimulation, whereas $\mathrm{Pg}$ is no longer available worldwide. It is very important to have an early detection based on Ca stimulated CT tests, but the question is "Are they safe?".

\section{Objective}

We thus aimed to write a systematic review of literature regarding side-effects for CT stimulating tests used for diagnosis of MTC.

\section{Materials and Methods}

A thorough review of the literature was done based on research and evidence-based practice using PubMed as search engine. The keywords used for search were: "calcitonin stimulation", or "calcitonin stimulation test", or "stimulated calcitonin", or "provocative test calcitonin", or "calcium loading test calcitonin", or "pentagastrin test", or "calcium pentagastrin test", or "side effects calcitonin stimulation" or "adverse reaction calcitonin stimulation". The search was performed between February and April 2020, and it was limited for English articles. No filter was applied for publication date. All types of articles were assessed, such as case reports, clinical trials, meta-analysis, reviews, systematic reviews. The process for study selection was based on the Preferred Reporting Items for Systematic Reviews and Meta-Analyses (PRISMA) 2009 checklist [12].

The focus of this paper was the safety of CT stimulation tests, so we assessed the side-effects, not the differences in their sensitivity or specificity, nor the thresholds for diagnosis and prognosis. First, we evaluated titles and abstracts of articles. The articles irrelevant for the study question and the articles that do not discuss the outcome that is of interest to this research were excluded, and relevant papers were selected. Furthermore, their full texts were read and screened for inclusion and exclusion criteria by this paper's first author. As inclusion criteria, we selected studies that specified: the substance used, the administration protocol used (quantity and time of administration), the number of subjects and the side effects noted by the authors. Exclusion criteria included: animal studies and studies with insufficient data such as a standardized protocol. Because in Ca stimulation tests various types of Ca were used, like Ca gluconate, Ca chloride, or Ca laevulatis, the tests were evaluated by the amount of elemental $\mathrm{Ca}$ in order to homogenize the test conditions. From another point of view, we screened whether the authors mentioned the patient's monitoring protocol, such as blood pressure (BP) and electrocardiogram (ECG) monitoring. In addition, we analyzed how the outcome was measured, the way of evaluating the adverse reactions, and its objectivity.

For further analysis, we classified the reported side effects by severity, as defined by United States Food and Drug Administration (FDA) 21312.32 Code of Federal Regulations [13], as follows: Adverse event (AE) - any untoward medical occurrence associated with the use of a drug in humans, whether or not considered drug related; Life-threatening adverse event (LTAE) - any adverse event that in the view of the investigator places the patient at immediate risk of death; it does not include an adverse event that, had it occurred in a more severe form, might have caused death; Serious adverse event (SAE) - any adverse event that in the view of the investigator results in any of the following outcomes: death, a lifethreatening adverse event, inpatient hospitalization or prolongation of existing hospitalization, a persistent or significant incapacity or substantial disruption of the ability to conduct normal life functions, or a congenital anomaly/birth defect; important medical events that may not result in death, be life-threatening, or require hospitalization may be considered serious when, based upon appropriate medical judgment, they may jeopardize the patient or subject and may require medical or surgical intervention to prevent one of the outcomes listed in this definition [13].

The classification was done for all side effects reported during Ca stimulation tests, and for historical interest, for Pg stimulation tests. Other substances had fewer studies and were excluded. Furthermore, a statistical analysis was performed using IBM SPSS Statistics version 20 .

\section{Rationale behind $\mathrm{Ca}$ or $\mathrm{Pg}$ stimulation test}

CT is a peptide secreted by parafollicular C-cells of the thyroid gland, which are neuroendocrine cells derived from ultimobranchial body. The CT secretion is controlled by ionized Ca levels through a G-protein coupled receptor called Ca-sensing-receptor (CaSR), which is expressed on the parafollicular C-cells $[14,15]$. The C-cells release $\mathrm{CT}$ during hypercalcemia, and the secretion decreases in response to hypocalcemia [16]. CaSR is also expressed by MTC cells, thus releasing $C T$ in response to $\mathrm{Ca}$ [17]. Therefore, administration of Ca may increase the sensitivity of CT testing (CT stimulation tests) [9]. For a better understanding of the possible side-effects, it is important to mention that CaSR activation also triggers gastrin secretion and gastric acid production, that further stimulate CT production $[18,19]$. CT suppresses osteoclast-mediated bone resorption and increases the renal excretion of Ca [16]. In humans, its physiologic role is still in question, but it proved efficient as treatment for osteoporosis or hypercalcemia and a tumor marker for the diagnosis and follow up of MTC.

$\mathrm{Pg}$ is a peptide that mimics natural gastrin and by binding to cholecystokinin-B/gastrin receptor, it stimulates the production of gastric acid by the oxyntic cells and the pancreatic secretion. Although it enhances gastrointestinal motility and stimulate the gallbladder, it delays gastric emptying time [20]. Normal thyroid tissue does not express measurable amounts of cholecystokinin-B/ gastrin receptor, but MTC can frequently express cholecystokinin$\mathrm{B} /$ gastrin receptors [21]. When Pg binds to this receptor it increases $C T$ production, thus $C T$ rises depending on how many receptors are present.

\section{Results}

During our first search we found 5494 articles that were furthermore assessed based on review of title and abstract. Among these, the full texts of 347 were furthermore read and evaluated for the inclusion and exclusion criteria. Finally, 25 articles were included in the present review ( $\triangleright$ Fig. 1). Among them, 12 studies tested both $\mathrm{Ca}$ and $\mathrm{Pg}$ separately in approximately the same group of 


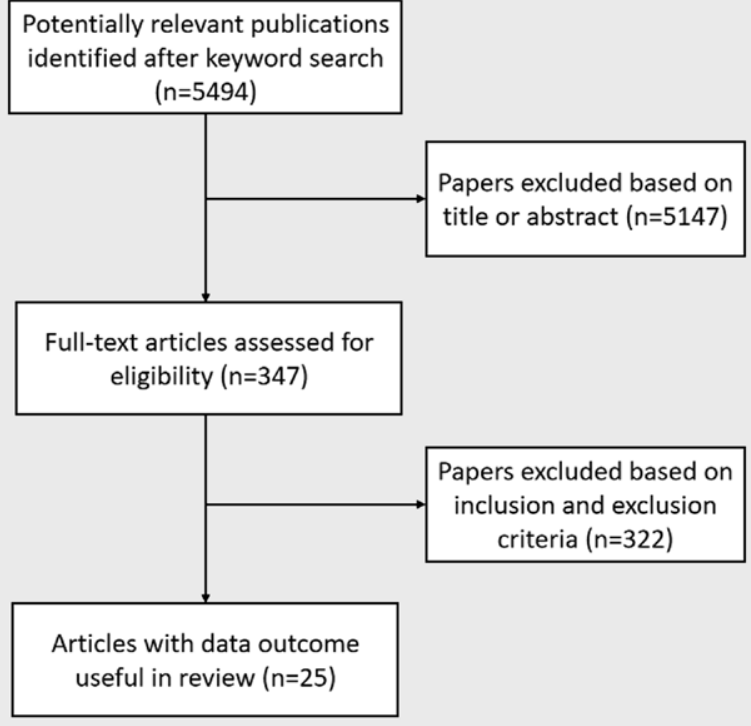

- Fig. 1 Prisma chart.

patients. From another point of view, we found a total of 19 articles about Ca stimulation test, 15 articles about Pg stimulation test, and 4 articles about combined $\mathrm{Pg}$ and $\mathrm{Ca}$ stimulation test ( Tables 1-3).

Regarding Ca stimulation test, the protocols involved different types of $\mathrm{Ca}$ that were evaluated by the amount of elemental Ca in order to homogenize the test conditions (Ca gluconate, Ca chloride, or Ca laevulatis), different amounts of Ca, different paths of administration [intravenous (iv) and orally], with some differences in dilution and infusion time ( $\triangleright$ Table $\mathbf{1}$ ). No significant differences were registered.

Regarding Pg stimulation test, the protocols involved the same amount of $\mathrm{Pg}(0.5 \mu \mathrm{g} / \mathrm{Kg} \mathrm{BW})$, the same path of administration (iv), with some differences in dilution and infusion time ( $>$ Table 2 ). No significant differences were registered.

\section{Test comparison}

After classification by severity of the reported side effects for $\mathrm{Ca}$ and $\mathrm{Pg}$ tests as defined by FDA 21312.32 Code of Federal Regulations [13] in AE, SAE and LTAE, the side effects after Pg test were significantly more severe than those reported after Ca stimulation test $(p<0.05)$.

Of much importance were the 12 studies that tested both $\mathrm{Ca}$ and $\mathrm{Pg}$ separately in approximately the same group of patients (9 studies tested in the same group [19,22-29], whereas 3 studies did not keep the same number of patients for both stimulants) $[4,30,31]$. After we applied the paired $t$-Test, the side effects after $\mathrm{Pg}$ test were significantly more severe than those reported after $\mathrm{Ca}$ stimulation test $(p<0.05)$.

A comparison was noted by authors themselves that performed both $\mathrm{Pg}$ and Ca test separately on the same patient or the combined $\mathrm{Pg}$-Ca test. Some authors used a questionnaire to be filled by the subjects for a better classification of type, duration or intensity of the side effects. Colombo et al. disclosed that almost all patients preferred the Ca test and that the intensity and duration of side effects were significantly lower during the test [4]. Also, between these two tests, warmth was noted in 134 of 309 Ca tests versus 21 of $195 \mathrm{Pg}$ tests $(p<0.0001)$, whereas gastric pain, nausea, and throat tightness in 108 of $195 \mathrm{Pg}$ tests versus 54 of 309 Ca tests recorded side effects $(p<0.0001)$ [4]. Furthermore, Doyle et al. also noted that all subjects receiving both substances preferred the $\mathrm{Ca}$ test due to a perception of more unpleasant adverse effects of $\mathrm{Pg}$ and declared that in healthy young to middle-aged adults, Ca seemed to be a better-tolerated test [31]. In another study, only mild side effects were reported after $\mathrm{Ca}$ infusion, whereas after Pg infusion $24 \%$ of the symptoms were classified as moderate [22]. In contrast, Telenius-Berg et al. noted that all patients have preferred the Pg tests to the infusion of Ca gluconate [32].

Concerning the duration of side effects, in one study it was noted that the majority of side effects (59\%) during the combined stimulation test lasted for less than 1 minute, whereas only 29.4 and $20 \%$ of side effects observed during the Ca or Pg stimulation tests, respectively, lasted less than 1 minute [30]. The duration of the symptoms as perceived by the patients reported by Thiem et al. ranged from only a few seconds up to 4 minutes with a median duration of 1.75 minutes after Ca test and 2 minutes after $\mathrm{Pg}$ [22]. In contrast, in Graze et al.'s analysis, the patients preferred the $\mathrm{Pg}$ test because the duration of discomfort after $\mathrm{Ca}$ infusion was longer, even though they more immediately uncomfortable after Pg [29].

Regarding the intensity, Vainas et al. used a semi-quantitative scale as mild (not bothersome for the patient), moderate (bothersome but tolerable), and severe (intolerable) [30]. The symptoms were of mild-to-moderate severity in the majority of cases, that is, 76, 77, and $61 \%$ after the combined, $\mathrm{Ca}$ and $\mathrm{Pg}$ stimulation tests, respectively [30]. The degree of the side effects was not described by others saying there is no "gold standard" for measurement of the intensity of these side effects [19].

Interestingly, Ubl et al. noted a significant gender-specific difference in side effects induced by stimulation tests [19]. Regarding the Pg test, higher incidences of most side effects were declared by male patients in comparison with female ones, excepting urgency to micturate and retro/substernal tightness. Concerning the Ca test, the incidences of altered taste, nausea, vomiting and abdominal cramping were higher in male patients than those in female ones. In contrast, the incidences of dizziness were reported to be increased in the female patients as compared to male ones $(p<0.05)$. The authors reported that female patients had fewer side effects by $\mathrm{Pg}$ test than by Ca test, whereas male patients may tolerate the Ca test better than the Pg test. The occurrence of urgency to micturate in female patients in comparison to male ones was significantly higher in both $\mathrm{Pg}$ and Ca stimulation tests $(\mathrm{p}=0.03)$. They declared that the reasons for the gender-related differences in the side effects were unknown [19].

\section{Hemodynamic monitoring}

The most frequent cardiovascular adverse events reported by some authors during stimulation tests were tachycardia [30,33-35] or bradycardia [36]. The severe cardiovascular side effects reported by two authors were atrial fibrillation, asystole and unresponsiveness after a Ca stimulation test [10] and after a combined $\mathrm{Ca}-\mathrm{Pg}$ 
- Table 1 Calcium (Ca) stimulation test (19 articles).

\begin{tabular}{|c|c|c|c|c|c|c|c|}
\hline $\begin{array}{l}\text { Authors } \\
\text { [Ref] }\end{array}$ & Year $^{*}$ & $\begin{array}{l}\text { Sub- } \\
\text { jects }\end{array}$ & Substance & $\begin{array}{l}\text { Administe- } \\
\text { red dose of } \\
\text { elemental Ca }\end{array}$ & $\begin{array}{l}\text { Time/ } \\
\text { rate of } \\
\text { infusion }\end{array}$ & Side effects & Severity \\
\hline $\begin{array}{l}\text { Thiem et al. } \\
\text { [22] }\end{array}$ & 2014 & 6 & $\begin{array}{l}\text { Ca gluconate } \\
10 \%\end{array}$ & $1 \mathrm{mg} / \mathrm{kg}$ BW iv & $2 \min$ & $\begin{array}{l}\text { Feeling of warmth in } 5 \text { (max duration } 4 \mathrm{~min} \text { ); } \\
\text { chest tightness in } 1 \text { (duration: } 3 \mathrm{sec} \text { ) }\end{array}$ & SAE \\
\hline $\begin{array}{l}\text { Farndon } \\
\text { et al. [23] }\end{array}$ & 1983 & 15 & Ca gluconate & $2 \mathrm{mg} / \mathrm{kg}$ BW iv & $45 \mathrm{sec}$ & Warmth, nausea & $\mathrm{AE}$ \\
\hline $\begin{array}{l}\text { Vainas et al. } \\
{[30]}\end{array}$ & 2013 & 25 & Ca gluconate & $2 \mathrm{mg} / \mathrm{kg}$ BW iv & $50 \mathrm{sec}$ & $\begin{array}{l}\text { Burning sensation in 19; nausea in 6; } \\
\text { numbness in 4; weakness in } 3 \text {; malaise in } 2 \text {; } \\
\text { abdominal discomfort in } 1 \text {; angina/palpita- } \\
\text { tions in } 1 \text {; faintness in } 1 \text {; flushing in } 1 \text {; no } \\
\text { side-effects in } 1\end{array}$ & SAE \\
\hline $\begin{array}{l}\text { Wells et al. } \\
\text { [24] }\end{array}$ & 1978 & 47 & Ca gluconate & $2 \mathrm{mg} / \mathrm{kg}$ BW iv & $1 \mathrm{~min}$ & $\begin{array}{l}\text { Generalized flush, urge to micturate, epigastric } \\
\text { fullness }\end{array}$ & $\mathrm{AE}$ \\
\hline $\begin{array}{l}\text { Emmertsen } \\
\text { et al. [25] }\end{array}$ & 1980 & 14 & $\begin{array}{l}\text { Ca laevulatis } \\
10 \%\end{array}$ & $2 \mathrm{mg} / \mathrm{kg}$ BW iv & & Nausea, general feeling of warmth & $\mathrm{AE}$ \\
\hline $\begin{array}{l}\text { Russo et al. } \\
\text { [10] }\end{array}$ & 2014 & 1 & $\begin{array}{l}\text { Ca gluconate } \\
10 \%\end{array}$ & $2 \mathrm{mg} / \mathrm{kg}$ BW iv & $\begin{array}{l}10 \mathrm{ml} / \\
\min \end{array}$ & Unresponsiveness, asystole & LTAE \\
\hline $\begin{array}{l}\text { Gharib et al. } \\
\text { [26] }\end{array}$ & 1987 & 104 & Ca gluconate & $\begin{array}{l}2 \mathrm{mg} / \mathrm{kg} \\
\mathrm{BW}_{\mathrm{iv}}^{\mathrm{a}}\end{array}$ & $5 \mathrm{~min}$ & $\begin{array}{l}\text { Mild sensation of generalized warmth. } \\
\text { Duration: less than } 5 \text { min }\end{array}$ & $\mathrm{AE}$ \\
\hline $\begin{array}{l}\text { Colombo } \\
\text { et al. [4] }\end{array}$ & 2012 & 144 & $\begin{array}{l}\text { Ca gluconate } \\
10 \%\end{array}$ & $\begin{array}{l}2.3 \mathrm{mg} / \mathrm{kg} \\
\text { BW iv }\end{array}$ & $\begin{array}{l}10 \mathrm{ml} / \\
\min \end{array}$ & $\begin{array}{l}\text { Abdominal cramping/urgency to micturate, } \\
\text { feeling of warmth, gastric pain, nausea, neck/ } \\
\text { throat tightness, flushing, headache, extremity } \\
\text { and/or lips paraesthesia }\end{array}$ & SAE \\
\hline $\begin{array}{l}\text { Mian et al. } \\
{[36]}\end{array}$ & 2014 & 91 & Ca gluconate & $\begin{array}{l}2.3 \mathrm{mg} / \mathrm{kg} \\
\mathrm{BW}^{\mathrm{b}} \text { iv }\end{array}$ & $\begin{array}{l}5 \mathrm{ml} / \\
\operatorname{ming}\end{array}$ & Bradycardia in 1 ; warmth & SAE \\
\hline $\begin{array}{l}\text { Papadakis } \\
\text { et al. [3] }\end{array}$ & 2015 & 55 & Ca gluconate & $\begin{array}{l}2.3 \mathrm{mg} / \mathrm{kg} \\
\text { BW iv }\end{array}$ & $3 \mathrm{~min}$ & $\begin{array}{l}\text { Brief bouts of nausea (duration: }<1 \mathrm{~min} \text { ), } \\
\text { headache/flushing }\end{array}$ & $\mathrm{AE}$ \\
\hline Doyle [31] & 2009 & 42 & $\begin{array}{l}\text { Ca gluconate } \\
10 \%\end{array}$ & $\begin{array}{l}2.5 \mathrm{mg} / \mathrm{kg} \\
\text { BW iv }\end{array}$ & $\begin{array}{l}10 \mathrm{ml} / \\
\min \end{array}$ & $\begin{array}{l}\text { Temporary flushing, feeling of warmth in } 98 \% \text {; } \\
\text { facial paraesthesia, altered gustatory sensation } \\
\text { in } 20 \% \text {. Duration: up to } 15 \text { min }\end{array}$ & $\mathrm{AE}$ \\
\hline $\begin{array}{l}\text { Ubl et al. } \\
\text { [19] }\end{array}$ & 2013 & 256 & $\begin{array}{l}\text { Ca gluconate } \\
10 \%\end{array}$ & $\begin{array}{l}2.5 \mathrm{mg} / \mathrm{kg} \\
\text { BW iv }\end{array}$ & & $\begin{array}{l}\text { Warmth feeling in } 64 \mathrm{M} / 63 \mathrm{~F} \text {; altered gustatory } \\
\text { sensation in } 33 \mathrm{M} / 18 \mathrm{~F} \text {; nausea in } 20 \mathrm{M} / 21 \mathrm{~F} \text {; } \\
\text { dizziness in } 13 \mathrm{M} / 23 \mathrm{~F} \text {; extremity or facial } \\
\text { paraesthesia in } 7 \mathrm{M} / 15 \mathrm{~F} \text {; urgency to micturate } \\
\text { in } 3 \mathrm{M} / 16 \mathrm{~F} \text {; retro/substernal tightness in } \\
3 \mathrm{M} / 7 \mathrm{~F} ; \text { abdominal cramping In } 4 \mathrm{M} / 5 \mathrm{~F} ; \\
\text { headache in } 4 \mathrm{M} / 4 \mathrm{~F} \text {; vomiting in } 3 \mathrm{M} / 0 \mathrm{~F} \text {; severe } \\
\text { fatigue in } 0 \mathrm{M} / 2 \mathrm{~F} \text {; memory impairment in } 0\end{array}$ & SAE \\
\hline $\begin{array}{l}\text { Rosario } \\
\text { et al. [49] }\end{array}$ & 2017 & 41 & $\begin{array}{l}\text { Ca gluconate } \\
10 \%\end{array}$ & $\begin{array}{l}2.5 \mathrm{mg} / \mathrm{kg} \\
\text { BW iv }\end{array}$ & & $\begin{array}{l}\text { Warm feeling or flushing in } 13 \text { ( } 31.7 \%) \text {; } \\
\text { paraesthesia in the extremities or lips in } 4 \\
(9.7 \%) \text {; abdominal cramping or urinary } \\
\text { urgency in } 3(7.3 \%) \text {; nausea in } 1(2.4 \%)\end{array}$ & $\mathrm{AE}$ \\
\hline $\begin{array}{l}\text { McLean } \\
\text { et al. [27] }\end{array}$ & 1984 & 44 & $\begin{array}{l}\text { Ca chloride } \\
10 \%\end{array}$ & $\begin{array}{l}3 \mathrm{mg} / \mathrm{kg} \\
\mathrm{BW} \mathrm{iv}^{\mathrm{c}}\end{array}$ & $5 \mathrm{ml} / \mathrm{min}$ & Nausea, perioral and digital paraesthesia & $\mathrm{AE}$ \\
\hline $\begin{array}{l}\text { Morimoto } \\
\text { et al. [38] }\end{array}$ & 1979 & 22 & $\begin{array}{l}\text { Ca gluconate } \\
8.5 \%\end{array}$ & $4 \mathrm{mg} / \mathrm{kg}$ BW iv & $1 \mathrm{~min}$ & Flush sensation. Duration: $1 \mathrm{~min}$ & $\mathrm{AE}$ \\
\hline $\begin{array}{l}\text { Morimoto } \\
\text { et al. [38] }\end{array}$ & 1979 & 8 & $\begin{array}{l}\text { Ca gluconate } \\
8.5 \%\end{array}$ & $4 \mathrm{mg} / \mathrm{kg}$ BW iv & $5 \mathrm{~min}$ & Flush sensation. Duration: several min & $\mathrm{AE}$ \\
\hline $\begin{array}{l}\text { Hennessy } \\
\text { et al. [28] }\end{array}$ & 1974 & 38 & Ca gluconate & $\begin{array}{l}15 \mathrm{mg} / \mathrm{kg} \\
\mathrm{BW} \text { ivd }\end{array}$ & $4 \mathrm{~h}$ & Mild nausea & $\mathrm{AE}$ \\
\hline $\begin{array}{l}\text { Graze et al. } \\
\text { [29] }\end{array}$ & 1978 & 107 & Ca gluconate & $\begin{array}{l}15 \mathrm{mg} / \mathrm{kg} \\
\text { BW iv }\end{array}$ & & Nausea in $75 \%$ & $\mathrm{AE}$ \\
\hline $\begin{array}{l}\text { Parthemore } \\
\text { et al. [50] }\end{array}$ & 1974 & $4^{* *}$ & Ca chloride & $150 \mathrm{mg}$ ive & $\begin{array}{l}5-10 \\
\min \end{array}$ & Facial blushing in $1 / 4$ & $\mathrm{AE}$ \\
\hline $\begin{array}{l}\text { Bevilacqua } \\
\text { et al. [51] }\end{array}$ & 2005 & 55 & Ca gluconate & $1 \mathrm{~g}$ orally ${ }^{f}$ & - & Well tolerated, no side effects & $\mathrm{AE}$ \\
\hline
\end{tabular}


> Table 2 Pentagastrin $(\mathrm{Pg})$ stimulation test (15 articles).

\begin{tabular}{|c|c|c|c|c|c|c|}
\hline $\begin{array}{l}\text { Authors } \\
\text { [Ref] }\end{array}$ & Year ${ }^{*}$ & $\begin{array}{l}\text { Sub- } \\
\text { jects }\end{array}$ & $\begin{array}{l}\text { Administered } \\
\text { dose }\end{array}$ & $\begin{array}{l}\text { Time of } \\
\text { infusion }\end{array}$ & Side effects & Severity \\
\hline $\begin{array}{l}\text { Gharib et al. } \\
\text { [26] }\end{array}$ & 1987 & 104 & $0.5 \mu \mathrm{g} / \mathrm{kg} \mathrm{BW}$ iv & $\leq 5 \mathrm{sec}$ & $\begin{array}{l}\text { Substernal discomfort, abdominal cramping, nausea. } \\
\text { Duration: less than } 2 \text { min }\end{array}$ & $\mathrm{AE}$ \\
\hline $\begin{array}{l}\text { Graze et al. } \\
{[29]}\end{array}$ & 1978 & 107 & $0.5 \mu \mathrm{g} / \mathrm{kg} \mathrm{BW}$ iv & $5 \mathrm{sec}$ & $\begin{array}{l}\text { Tightness in the chest, generalized unpleasant feeling. } \\
\text { Duration: } 2-5 \mathrm{~min}\end{array}$ & SAE \\
\hline $\begin{array}{l}\text { Wells et al. } \\
\text { [24] }\end{array}$ & 1978 & 47 & $0.5 \mu \mathrm{g} / \mathrm{kg}$ BW iv & & $\begin{array}{l}\text { Sensation of tightening in the pharynx and retrosternal } \\
\text { area, epigastric fullness }\end{array}$ & SAE \\
\hline $\begin{array}{l}\text { Emmertsen } \\
\text { et al. [25] }\end{array}$ & 1980 & 14 & $0.5 \mu \mathrm{g} / \mathrm{kg} \mathrm{BW}$ iva & & $\begin{array}{l}\text { Generalized unpleasantness with oppression and } \\
\text { abdominal discomfort. Duration: about } 2 \mathrm{~min}\end{array}$ & $\mathrm{AE}$ \\
\hline $\begin{array}{l}\text { Hennessy } \\
\text { et al. [28] }\end{array}$ & 1974 & 38 & $0.5 \mu \mathrm{g} / \mathrm{kg} B W \mathrm{iv}^{\mathrm{b}}$ & $5-10 \mathrm{sec}$ & Mild epigastric distress. Duration $1-2$ min & $\mathrm{AE}$ \\
\hline $\begin{array}{l}\text { Wells et al. } \\
\text { [52] }\end{array}$ & 1975 & 4 & $0.5 \mu \mathrm{g} / \mathrm{kg}$ BW ivc & & Mild epigastric pain. Duration: $45-60 \mathrm{sec}$ & $\mathrm{AE}$ \\
\hline $\begin{array}{l}\text { Rude et al. } \\
\text { [33] }\end{array}$ & 1977 & 4 & $0.5 \mu \mathrm{g} / \mathrm{kg} B W \mathrm{iv}^{\mathrm{d}}$ & $10 \mathrm{sec}$ & $\begin{array}{l}\text { Moderate to severe substernal pressure, dyspnea, mild } \\
\text { tachycardia and tachypnea in } 2 / 4 \text {. Duration: } 2 \text { min }\end{array}$ & SAE \\
\hline $\begin{array}{l}\text { Doyle et al. } \\
\text { [31] }\end{array}$ & 2009 & 50 & $0.5 \mu \mathrm{g} / \mathrm{kg}$ BW iv & & $\begin{array}{l}\text { Retro/substernal tightness/abdominal cramping in } 94 \% \text {, } \\
\text { extremity paraesthesia in } 74 \% \text {, feeling of warmth in } \\
30 \% \text {, dizziness in } 12 \% \text {, nausea, urge to micturate, } \\
\text { metallic taste a few subjects each. Duration: } 1-2 \text { min }\end{array}$ & SAE \\
\hline $\begin{array}{l}\text { Colombo } \\
\text { et al. [4] }\end{array}$ & 2012 & 74 & $0.5 \mu \mathrm{g} / \mathrm{kg}$ BW iv & & $\begin{array}{l}\text { Abdominal cramping/urgency to micturate, feeling of } \\
\text { warmth, gastric pain, nausea, neck/throat tightness, } \\
\text { flushing, headache, extremity and/or lips paraesthesia }\end{array}$ & SAE \\
\hline Ubl et al. [19] & 2013 & 256 & $0.5 \mu \mathrm{g} / \mathrm{kg}$ BW iv & & $\begin{array}{l}\text { Warmth feeling in } 64 \mathrm{M} / 57 \mathrm{~F} \text {; nausea in } 53 \mathrm{M} / 34 \mathrm{~F} \text {; altered } \\
\text { gustatory sensation in } 30 \mathrm{M} / 19 \mathrm{~F} \text {; dizziness in } 24 \mathrm{M} / 17 \mathrm{~F} \text {; } \\
\text { abdominal cramping in } 24 \mathrm{M} / 14 \mathrm{~F} \text {; extremity or facial } \\
\text { paraesthesia in } 20 \mathrm{M} / 13 \mathrm{~F} \text {; retro/substernal tightness in } \\
12 \mathrm{M} / 11 \mathrm{~F} \text {; headache in } 11 \mathrm{M} / 7 \mathrm{~F} \text {; urgency to micturate in } \\
3 \mathrm{M} / 5 \mathrm{~F} \text {; vomiting in } 7 \mathrm{M} / 1 \mathrm{~F} \text {; memory impairment in } \\
1 \mathrm{M} / 0 \mathrm{~F}\end{array}$ & SAE \\
\hline $\begin{array}{l}\text { Vainas et al. } \\
\text { [30] }\end{array}$ & 2013 & 15 & $0.5 \mu \mathrm{g} / \mathrm{kg}$ BW iv & & $\begin{array}{l}\text { Burning sensation in } 7 \text {; weakness in } 5 \text {; abdominal } \\
\text { discomfort in } 5 \text {; nausea in } 4 \text {; angina/palpitations in } 2 \text {; } \\
\text { tachycardia in } 1 \text {; faintness in } 1 \text {; numbness in } 1 \text {; hunger in } \\
1 \text {; no side-effects in } 2\end{array}$ & SAE \\
\hline $\begin{array}{l}\text { Thiem et al. } \\
\text { [22] }\end{array}$ & 2014 & 6 & $0.5 \mu \mathrm{g} / \mathrm{kg}$ BW iv & & $\begin{array}{l}\text { Feeling of warmth in } 5 \text { (max duration: } 4 \text { min); chest } \\
\text { tightness in } 3 \text { (max duration: } 3 \text { min); abdominal cramps } \\
\text { in } 2 \text { (max duration: } 3 \text { min); nausea in } 2 \text { (max duration: } 2 \\
\text { min); extremity paraesthesia in } 2 \text { (max duration: } 2 \text { min); } \\
\text { flushing in } 2 \text { (max duration: } 2 \text { min); pruritus in } 1 \\
\text { (duration: } 4 \text { min); dizziness in } 1 \text { (duration: } 1 \text { min); } \\
\text { alterations in the sense of taste in } 1 \text { (duration: } 1 \text { min); } \\
\text { need to cough in } 1 \text { (duration: } 10 \mathrm{sec} \text { ); headache in } 1 \\
\text { (duration: } 3 \mathrm{sec)}\end{array}$ & SAE \\
\hline $\begin{array}{l}\text { Verdy et al. } \\
\text { [53] }\end{array}$ & 1978 & 39 & $0.5 \mu \mathrm{g} / \mathrm{kg}$ BW ive & $10-15 \mathrm{sec}$ & $\begin{array}{l}\text { Mild substernal pressure and dyspnea. Duration: less } \\
\text { than } 1-2 \text { min. Flushing }\end{array}$ & SAE \\
\hline $\begin{array}{l}\text { Farndon et al. } \\
\text { [23] }\end{array}$ & 1983 & 15 & $0.5 \mu \mathrm{g} / \mathrm{kg}$ BW iv & $15 \mathrm{sec}$ & Abdominal cramps, nausea & $\mathrm{AE}$ \\
\hline $\begin{array}{l}\text { Mclean et al. } \\
\text { [27] }\end{array}$ & 1984 & 44 & $0.5 \mu \mathrm{g} / \mathrm{kg} \mathrm{BW} \mathrm{iv} \mathrm{f}^{\mathrm{f}}$ & $1 \mathrm{~min}$ & Transient but severe abdominal discomfort, nausea & $\mathrm{AE}$ \\
\hline
\end{tabular}

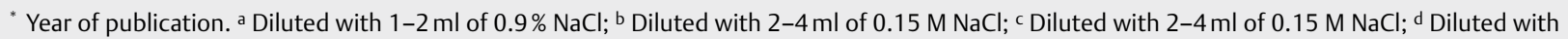
$5 \mathrm{ml}$ of $0.9 \% \mathrm{NaCl}$; e Diluted with saline; ${ }^{\mathrm{f}}$ Diluted with $5-10 \mathrm{ml}$ of $0.9 \% \mathrm{NaCl}$. KgBW: Kilograms per body weight; iv: Intravenous; M: Male; F: Female; AE: Adverse event; SAE: Serious adverse event. 
- Table 3 Combined pentagastrin $(\mathrm{Pg})$ and calcium (Ca) stimulation test (4 articles).

\begin{tabular}{|c|c|c|c|c|c|c|c|}
\hline Authors [Ref] & Year ${ }^{*}$ & Subjects & Substance & $\begin{array}{l}\text { Administe- } \\
\text { red dose }\end{array}$ & $\begin{array}{l}\text { Time of } \\
\text { infusion }\end{array}$ & Side effects & Severity \\
\hline Drucker [37] & 1981 & 1 & $\begin{array}{l}\text { Ca gluconate } \\
\mathrm{Pg}\end{array}$ & $\begin{array}{l}2 \mathrm{mg} / \mathrm{kg} B W \\
\text { iv } 0.5 \mu \mathrm{g} / \mathrm{kg} \\
B W \text { iv }\end{array}$ & $\begin{array}{l}1 \mathrm{~min} 5 \\
\mathrm{sec}\end{array}$ & $\begin{array}{l}\text { Unresponsiveness (short period), } \\
\text { high-rate atrial fibrillation } \\
\text { (duration: } 4 \mathrm{~h} \text { ) }\end{array}$ & LTAE \\
\hline $\begin{array}{l}\text { Simpson et al. } \\
\text { [34] }\end{array}$ & 1990 & 210 & $\begin{array}{l}\text { Ca gluconate } \\
\mathrm{Pg}\end{array}$ & $\begin{array}{l}2 \mathrm{mg} / \mathrm{kg} \mathrm{BW} \\
\text { iv } 0.5 \mu \mathrm{g} / \mathrm{kg} \\
B W \text { iv }\end{array}$ & $\begin{array}{l}1 \mathrm{~min} \text { few } \\
\mathrm{sec}\end{array}$ & $\begin{array}{l}\text { Flushing; sweating; pharyngeal, } \\
\text { retrosternal or epigastric pressure; } \\
\text { general weakness. Serious complica- } \\
\text { tions including malaise and prostration } \\
\text { for } 24 \text { to } 48 \text { hours, cardiac arrhythmias } \\
\text { and hypotension }(<1 \%)\end{array}$ & SAE \\
\hline $\begin{array}{l}\text { Van Lathem et al. } \\
\text { [54] }\end{array}$ & 1992 & 78 & $\begin{array}{l}\text { Ca chloride } \\
\text { Pg }\end{array}$ & $\begin{array}{l}3 \mathrm{mg} / \mathrm{kg} \text { BWa } \\
\text { iv } 0.5 \mu \mathrm{g} / \mathrm{kg} \\
\text { BW iv }\end{array}$ & $10 \mathrm{~min}$ & $\begin{array}{l}\text { Generalized warmth Hypotension, } \\
\text { abdominal cramps, nausea. Duration: } \\
\text { less than } 2 \text { min }\end{array}$ & SAE \\
\hline Vainas et al. [30] & 2013 & 26 & $\begin{array}{l}\text { Ca gluconate } \\
\mathrm{Pg}\end{array}$ & $\begin{array}{l}2 \mathrm{mg} / \mathrm{kg} \mathrm{BW} \\
\text { iv } 0.5 \mu \mathrm{g} / \mathrm{kg} \\
\text { BW iv }\end{array}$ & $\begin{array}{l}50 \sec 10 \\
\text { sec }\end{array}$ & $\begin{array}{l}\text { Burning sensation in } 25 \text {; flushing in } 9 \text {; } \\
\text { weakness in } 5 \text {; abdominal discomfort } \\
\text { in } 5 \text {; nausea in } 4 \text {; numbness in } 2 \text {; tachy- } \\
\text { cardia in } 2 \text {; hunger in } 2 \text {; dysarthria in } 1 \text {; } \\
\text { malaise in } 1 \text {; no side-effects in } 1\end{array}$ & SAE \\
\hline
\end{tabular}

* Year of publication; a Diluted with up to $10 \mathrm{ml}$ of sterile water. KgBW: Kilograms per body weight; iv: Intravenous; SAE: Serious adverse event; LTAE: Life-threatening adverse event.

stimulation test [37]. Mian et al. outlined that in 90 of 91 cases, no heart rate variations were observed and declared that patients should be reassured about the safety of the test [36]. Moreover, Mian et al. stress out the importance of preventive evaluation of some clinical, instrumental, and biochemical aspects of each patient, in consideration of the proarrhythmic risks linked to the infusion of Ca gluconate [36]. Some studies reported that no significant changes were seen on ECG [38], or no ECG monitoring was mentioned at all.

\section{Discussion}

Over time various substances and protocols have been used for CT stimulation tests for MTC diagnosis. Stimulation tests have also been used in other disorders besides MTC. Pg was studied for various gastric function tests [39-43], for diagnosis of carcinoid syndrome [44], for diagnosis and follow up of VIPoma [45] and even for anxiety psychophysiology research [46]. The Ca gluconate test was also considered for the diagnosis of carcinoid syndrome [44], whether the combined $\mathrm{Ca}-\mathrm{Pg}$ test was studied for the diagnosis of somatostatinoma $[47,48]$. The indication to perform CT stimulating tests has changed in the last years. The new indications are: to help differentiate thyroid causes of elevated CT apart from nonthyroid sources $[6,9]$, to help determine whether the patients with slightly elevated basal CT could/could not be candidates for surgery $[6,7,10]$ and to help indicate the right moment for prophylactic thyroidectomy in children with Multiple Endocrine Neoplasia (MEN) when basal CT is normal [9-11]. Unfortunately, CT stimulation tests failed to accurately differentiate between micro-MTC and C-Cell hyperplasia $(\mathrm{CCH})[5]$.
A clear difference between side-effects and severe complications has to be drawn. For a better attempt to an objective analysis, we classified the reported side effects by all the authors by severity, as defined by FDA 21312.32 Code of Federal Regulations [13]. For historical interest, our results indicated that adverse reactions after $\mathrm{Pg}$ test were significantly more severe than those noted after Ca stimulation test. Among the types of Ca, Ca gluconate has the most studies so far. No significant differences could be noted between the amount of injected elemental Ca or time of infusion.

\section{Calcium stimulation tests}

\section{Mild side effects}

The majority of side-effects after Ca administration are mild, and represented mostly by: feeling of warmth, nausea, altered gustatory sensation and headache. SAE like tachycardia/bradycardia, neck/chest tightness can occur with lower frequency.

\section{Severe complications}

In our review, only one LTAE was reported after Ca stimulation test: asystole [10]. This outlines the importance of hemodynamic monitoring, always with both BP and ECG. Continuous cardiac monitoring during the test should be performed to guarantee rapid intervention should an adverse cardiovascular event occur $[10,36]$.

\section{Pentagastrin stimulation tests}

\section{Mild side effects}

The majority of side-effects after Pg administration are mild-tomoderate, and represented mostly by neck/chest tightness and gastro-intestinal side-effects. 


\section{Severe complications}

In our review, no LTAE was reported after Pg stimulation test. However, hemodynamic monitoring with both BP and ECG is necessary because arrhythmias can occur.

\section{Ca stimulation test - Protocol}

According to studied literature and own experience, the current authors recommend the following protocol. The recommended substance for CT stimulation test is Ca gluconate because it has been most studied so far.

Pre-test Patients should be informed about possible side-effects and the test should be performed after signing an informed consent. The test should not be performed until a clinical and lab evaluation of the patient is done, regarding exclusion criteria. The exclusion criteria proposed are:

- Hyper-/hypocalcemia, hyper-/hypokalemia;

- Kidney failure stages IV-V;

- Cyanogenic congenital heart diseases, arrhythmogenic heart diseases, prolonged QT or

- PR interval, grade II-III atrioventricular block, heart rate $<40 /$ min or $>110 / \mathrm{min}$, history of myocardial infarction;

- Pregnancy.

To document that the patient has no exclusion criteria, the following investigations are required: serum total and ionized $\mathrm{Ca}$, potassium; serum creatinine, and urea; cardiology check-up with BP and 12 leads of ECG. More than that, the patient should be monitored with both BP and ECG pre-test, during the test and following the test.

Two peripheral venous pathways (cannulas) should be put at the level of each forearm: one for blood collection for CT measurement and one for Ca injection. One CT sample should be collected before Ca administration.

Test The test should be performed on an empty stomach and with the patient lying down. The recommended protocol for CT stimulation test is iv administration of $2.4 \mathrm{mg} / \mathrm{Kg}$ BW of elemental Ca, calculated in advance and adjusted to the patient's ideal weight, to avoid overdosing, with Lorentz formula: Ideal Weight $(\mathrm{Kg})=$ Height $(\mathrm{cm})-100-[$ Height $(\mathrm{cm})-150] / 2$. The recommended total time of infusion is of 3-5 minutes, depending on the patient's tolerance. For that a continuous dialogue with the patient is mandatory. Three CT samples are collected after Ca infusion at 2,5 , and 10 minutes after administration of Ca gluconate. As previously mentioned, the patient should be continuously monitored with both BP and ECG during the test.

Post-test After slowly injection of Ca gluconate, a $500 \mathrm{ml}$ saline infusion $(0.9 \% \mathrm{NaCl})$ should be slowly administered, to facilitate urinary excretion of $\mathrm{Ca}$. Even though serious cardiac adverse events develop mostly in the first 5 minutes after Ca infusion, the patient should be monitored with both BP and ECG as previously mentioned for another 60-180 minutes after the end of the test.

The total of four CT samples collected during Ca stimulation test (before and at 2, 5, and 10 minutes after administration of $\mathrm{Ca}$ ) should be sent to the laboratory for analysis in good time. Patient participation is of approximately 15 minutes, time elapsed for $\mathrm{Ca}$ gluconate administration and blood collection, then another 60
180 minutes after the end of the test for monitoring and saline infusion.

\section{Conclusion}

CT stimulation tests have great value and could help to: differentiate thyroid causes of elevated CT apart from non-thyroid sources, determine whether the patients with slightly elevated basal CT could/could not be candidates for surgery, and indicate the right moment for prophylactic thyroidectomy in children with MEN syndromes when with normal basal CT. Current authors recommend performing $\mathrm{Ca}$ CT stimulation test when needed, considering preventive evaluation of some clinical, instrumental, and biochemical aspects of each patient. Precise instructions should be followed before the test and furthermore continuous cardiac monitoring is essential during the test and post-test period to minimize the possibility of a serious event.

\section{Conflict of Interest}

The authors declare that they have no conflict of interest.

\section{References}

[1] Medullary thyroid cancer: Surgical treatment and prognosis UpToDate n.d https://www.uptodate.com/contents/medullarythyroid-cancer-surgical-treatment-and-prognosis?search = Medullary thyroid cancer: Treatment and prognosis.\&source = search_ result\&selectedTitle $=1 \sim 88 \&$ usage_type $=$ default\&display_rank $=1$ (accessed October 19 2020)

[2] Toledo SPA, Lourenço DM, Santos MA et al. Hypercalcitoninemia is not pathognomonic of medullary thyroid carcinoma. Clinics 2009; 64: 699-706

[3] Papadakis G, Keramidas I, Triantafillou E et al. Association of basal and calcium-stimulated calcitonin levels with pathological findings after total thyroidectomy. Anticancer Res 2015; 35: 4251-4258

[4] Colombo C, Verga U, Mian C et al. Comparison of calcium and pentagastrin tests for the diagnosis and follow-up of medullary thyroid cancer. J Clin Endocrinol Metab 2012; 97: 905-913

[5] Niederle MB, Scheuba C, Gessl A et al. Calcium-stimulated calcitonin - The "new standard" in the diagnosis of thyroid C-cell disease-clinically relevant gender-specific cut-off levels for an "old test.". Biochem Med (Zagreb) 2018; 28: 030710

[6] Niederle MB, Scheuba C, Riss P et al. Early Diagnosis of Medullary Thyroid Cancer: Are Calcitonin Stimulation Tests Still Indicated in the Era of Highly Sensitive Calcitonin Immunoassays? Thyroid 2020; 30: 974-984

[7] Fugazzola L, Di Stefano M, Censi S et al. Basal and stimulated calcitonin for the diagnosis of medullary thyroid cancer: updated thresholds and safety assessment. J Endocrinol Invest 2020; 44: 587-597

[8] Costante G, Meringolo D, Durante $C$ et al. Predictive value of serum calcitonin levels for preoperative diagnosis of medullary thyroid carcinoma in a cohort of 5817 consecutive patients with thyroid nodules. J Clin Endocrinol Metab 2007; 92: 450-455

[9] Wells SA, Asa SL, Dralle H et al. Revised American thyroid association guidelines for the management of medullary thyroid carcinoma. Thyroid 2015; 25: 567-610 
[10] Russo M, Scollo C, Padova G et al. Cardiac arrest after intravenous calcium administration for calcitonin stimulation test. Thyroid 2014; 24: 606-607

[11] Niederle B, Sebag F, Brauckhoff M. Timing and extent of thyroid surgery for gene carriers of hereditary $C$ cell disease - A consensus statement of the European Society of Endocrine Surgeons (ESES). Langenbeck's Arch Surg 2014; 399: 185-197

[12] Moher D, Liberati A, Tetzlaff J et al. Preferred reporting items for systematic reviews and meta-analyses: The PRISMA statement. BM] 2009; 339: 332-336

[13] CFR - Code of Federal Regulations Title 21 n.d https://www. accessdata.fda.gov/scripts/cdrh/cfdocs/cfcfr/cfrsearch.cfm?fr $=312.32$ accessed October 19 2020;

[14] Hofer AM, Brown EM. Extracellular calcium sensing and signalling. Nat Rev Mol Cell Biol 2003; 4: 530-538

[15] Garrett JE, Tamir H, Kifor O et al. Calcitonin-secreting cells of the thyroid express an extracellular calcium receptor gene. Endocrinology 1995; 136: 5202-5211

[16] Gardner DG, Shoback DM. Greenspan's Basic \& Clinical Endocrinology. Ninth Edition; New York: McGraw-Hill; 2011

[17] Freichel M, Zink-Lorenz A, Holloschi A et al. Expression of a calciumsensing receptor in a human medullary thyroid carcinoma cell line and its contribution to calcitonin secretion. Endocrinology 1996; 137 : 3842-3848

[18] Ceglia L, Harris SS, Rasmussen HM et al. Activation of the calcium sensing receptor stimulates gastrin and gastric acid secretion in healthy participants. Osteoporos Int 2009; 20: 71-78

[19] Ubl P, Gincu T, Keilani M et al. Comparison of side effects of pentagastrin test and calcium stimulation test in patients with increased basal calcitonin concentration: The gender-specific differences. Endocrine 2014; 46: 549-553

[20] Pentagastrin | DrugBank Online n.d https:/go.drugbank.com/drugs/ (accessed February 22, 2021)

[21] Reubi JC, Schaer JC, Waser B. Cholecystokinin(CCK)-A and CCK-B/ gastrin receptors in human tumors. Cancer Res 1997; 57: 1377-1386

[22] Thiem U, Marculescu R, Cejka D et al. Low-dose calcium versus pentagastrin for stimulation of calcitonin in chronic hemodialysis patients: A pilot study. J Clin Endocrinol Metab 2014; 99: 4704-4711

[23] Farndon JR, Lewis KR, Dale JK et al. Histamine and calcitonin release from medullary thyroid carcinoma. Cancer 1983; 51: 1221-1225

[24] Wells SA, Baylin SB, Linehan WM et al. Provocative agents and the diagnosis of medullary carcinoma of the thyroid gland. Ann Surg 1978; 188: 139-141

[25] Emmertsen K, Nielsen HE, Mosekilde L et al. Pentagastrin, calcium and whisky stimulated serum calcitonin in medullary carcinoma of the thyroid. Acta Oncol (Madr) 1980; 19: 85-89

[26] Gharib H, Kao PC, Heath H. Determination of Silica-Purified Plasma Calcitonin for the Detection and Management of Medullary Thyroid Carcinoma: Comparison of Two Provocative Tests. Mayo Clin Proc 1987; 62: 373-378

[27] McLean GW, Rabin D, Moore L et al. Evaluation of provocative tests in suspected medullary carcinoma of the thyroid: Heterogeneity of calcitonin responses to calcium and pentagastrin. Metabolism 1984; 33: $790-796$

[28] Hennessy JF, Wells SA, Ontjes DA et al. A comparison of pentagastrin injection and calcium infusion as provocative agents for the detection of medullary carcinoma of the thyroid. J Clin Endocrinol Metab 1974; 39: 487-495
[29] Graze K, Spiler I], Tashjian AH et al. Natural History of Familial Medullary Thyroid Carcinoma: Effect of a Program for Early Diagnosis. N Engl J Med 1978; 299: 980-985

[30] Vainas I, Marthopoulos A, Chrisoulidou A et al. Calcitonin stimulation tests for the early diagnosis and follow-up of patients with $C$ cell disease: A descriptive analysis. Hippokratia 2013; 17: 246-251

[31] Doyle P, Düren C, Nerlich K et al. Potency and tolerance of calcitonin stimulation with high-dose calcium versus pentagastrin in normal adults. J Clin Endocrinol Metab 2009; 94: 2970-2974

[32] Telenius-Berg M, Almqvist S, Berg B et al. Screening for medullary carcinoma of the thyroid in families with Sipple's syndrome: evaluation of new stimulation tests. Eur J Clin Invest 1977; 7: 7-16

[33] Rude RK, Singer FR. Comparison of serum calcitonin levels after a 1-minute calcium injection and after pentagastrin injection in the diagnosis of medullary thyroid carcinoma. J Clin Endocrinol Metab 1977; 44: 980-983

[34] Simpson W], Carruthers JS, Malkin D. Results of a screening program for c-cell disease (medullary thyroid cancer and c-cell hyperplasia). Cancer 1990; 65: 1570-1576

[35] Cohen SL, Grahame-Smith D, Macintyre I et al. Alcohol-stimulated calcitonin release in medullary carcinoma of the thyroid. Lancet 1973; 302: 1172-1174

[36] Mian C, Perrino M, Colombo C et al. Refining calcium test for the diagnosis of medullary thyroid cancer: Cutoffs, procedures, and safety. J Clin Endocrinol Metab 2014; 99: 1656-1664

[37] Drucker D. Atrial Fibrillation after Administration of Calcium and Pentagastrin. New Engl J Med 1981; 304: 1427-1428

[38] Morimoto S, Onishi T, Okada Y et al. Comparison of Human Calcitonin Secretion After Calcium Infusion in Young Normal and in Elderly Subjects. Endocrinol Jpn 1979; 26: 207-211

[39] Aylward M, Bourke JB. A possible reaction to pentagastrin. Lancet 1969; 2: 267

[40] Barrowman JA, Herxheimer A, Kits TP. Unwanted effects of pentagastrin. Clin Pharmacol Ther 1970; 11: 862-868

[41] Ewers HR, Brouwers HP, Merguet P et al. [Side effects after stimulation of gastric secretion with pentagastrin (author's transl)]. Med Klin 1976; 71: 19-23

[42] McCloy RF. Acute reaction to Pentagastrin. Lancet 1977; 1: 548

[43] Acar O, Schwizer W, Hauri D. Demonstration of acid secretion in the gastric pouch through the pentagastrin stimulation test. Urol Int 2003; 70: $178-180$

[44] Ahlman H, Dahlström A, Grönstad K et al. The pentagastrin test in the diagnosis of the carcinoid syndrome. J Cardiovasc Pharmacol 1985; 7: S86-S88

[45] Brunt LM, Mazoujian G, O’Dorisio TM et al. Stimulation of vasoactive intestinal peptide and neurotensin secretion by pentagastrin in a patient with VIPoma syndrome. Surgery 1994; 115: 362-369

[46] Radu D, Åhlin A, Svanborg P et al. Pentagastrin test for anxiety - Psychophysiology and personality. Psychopharmacology (Berl) 2003; 166 : 139-145

[47] Somers G, Pipeleers-Marichal M, Gepts W et al. A case of duodenal somatostatinoma: diagnostic usefulness of calcium--pentagastrin test. Gastroenterology 1983; 85: 1192-1198

[48] Budmiger H, Bühler H, Häcki W et al. Comparative diagnostic value of the calcium-pentagastrin test versus the tolbutamide test in a patient with a somatostatinoma. Gastroenterology 1987; 92: 800-804

[49] Rosario PW, Calsolari MR. Basal Serum Calcitonin, After Calcium Stimulation, and in the Needle Washout of Patients with Thyroid Nodules and Mild or Moderate Basal Hypercalcitoninemia. Horm Metab Res 2017; 49: 129-134 
[50] Parthemore JG, Deftos LJ. A short calcium (Ca) infusion in the diagnosis of medullary thyroid carcinoma (MTC). J Clin Endocrinol Metab 1974; 22: 108-111

[51] Bevilacqua M, Dominguez LJ, Righini V et al. Dissimilar PTH, gastrin, and calcitonin responses to oral calcium and peptones in hypocalciuric hypercalcemia, primary hyperparathyroidism, and normal subjects: A useful tool for differential diagnosis. J Bone Miner Res 2006; 21: 406-412

[52] Wells SA, Ontjes DA, Cooper CW et al. The early diagnosis of medullary carcinoma of the thyroid gland in patients with multiple endocrine neoplasia type II. Ann Surg 1975; 182: 362-370
[53] Verdy M, Cholette JP, Cantin J et al. Calcium infusion and pentagastrin injection in diagnosis of medullary thyroid carcinoma. Can Med Assoc J 1978; 119: 29-35

[54] van Lathem JJM, Vermaak WJH, Kuyl JM et al. Experience with a provocative test of calcitonin release as a prospective screening for preclinical medullary thyroid carcinoma in men type $2 \mathrm{~A}$ family members. J Clin Lab Anal 1992; 6: 384-390 